\title{
Francis Harry Crick (1916-2004): Co-discoverer of the structure of DNA
}

Siang Yong $\underline{\operatorname{Tan}}^{1}$, MD, JD, Alli N McCoy ${ }^{2}$, MD, PhD

\author{
I am the family face; \\ Flesh perishes, I live on, \\ Projecting trait and trace \\ Through time to times anon, \\ And leaping from place to place \\ Over oblivion.
}

- Thomas Hardy (1917)

W hen Thomas Hardy wrote about heredity, nothing was known about its molecular basis. In 1953, two brilliant scientists, James Watson and Francis Crick, discovered the DNA double helix and, in the process, transformed science and ushered in the era of the gene.

Francis Harry Crick was born in 1916 in Northampton, England, into a family that ran a shoe factory. He attended University College London, receiving his Bachelor of Science in 1937 with a major in physics. Initially, he undertook graduate work, studying the viscosity of water at high temperatures, a topic he would later refer to as "the dullest problem imaginable". His studies were literally interrupted by World War II when, in 1939, a bomb went through the roof of his laboratory and damaged his experimental setup. Unable to continue, he embarked on military research on magnetic and acoustic mines for the British Admiralty. He was so skilled at his job that he was offered a position of leadership in the military, but he rejected this in favour of biological research.

THE DISCOVERY Crick said that he used the 'gossip test' to determine his career direction. The 'gossip test' is simply that whatever you find yourself gossiping about is what you are really interested in. Indeed, this test helped him identify two major areas of interest - molecular biology and neuroscience. During his lifetime, he would make lofty contributions to both.

Crick transitioned from physics and military research to the field of molecular biology because in his mind, it stood at the boundary between the living and non-living, and thus held answers to the fundamental question of what life is. In 1947, he joined the Strangeways Research Laboratory in Cambridge, where he mastered both organic chemistry and X-ray crystallography. Two years later, he joined the Cavendish Laboratory at the University of Cambridge, England, under the guidance of Max Perutz. In his years at Cavendish, Crick and his collaborators worked on a theory of X-ray diffraction by a symmetrical helix. Although he and his colleagues were beaten by Linus Pauling in the attempt to identify the structure of the protein's alpha helix, Crick learnt important lessons that he would apply to the interpretation of DNA data. It was his work at Cavendish that brought Crick into contact with Watson, which led to the duo's final elucidation of the structure of DNA, the molecule responsible for genetic inheritance. Crick was 35 years of age when he started work for his graduate thesis on the structure of haemoglobin. Most unusually, he only completed the requirements for his Doctor of Philosophy degree after winning the Nobel Prize for his co-discovery of DNA structure in 1962! The exciting details of Crick and Watson's work are described in another $S M J$ article.

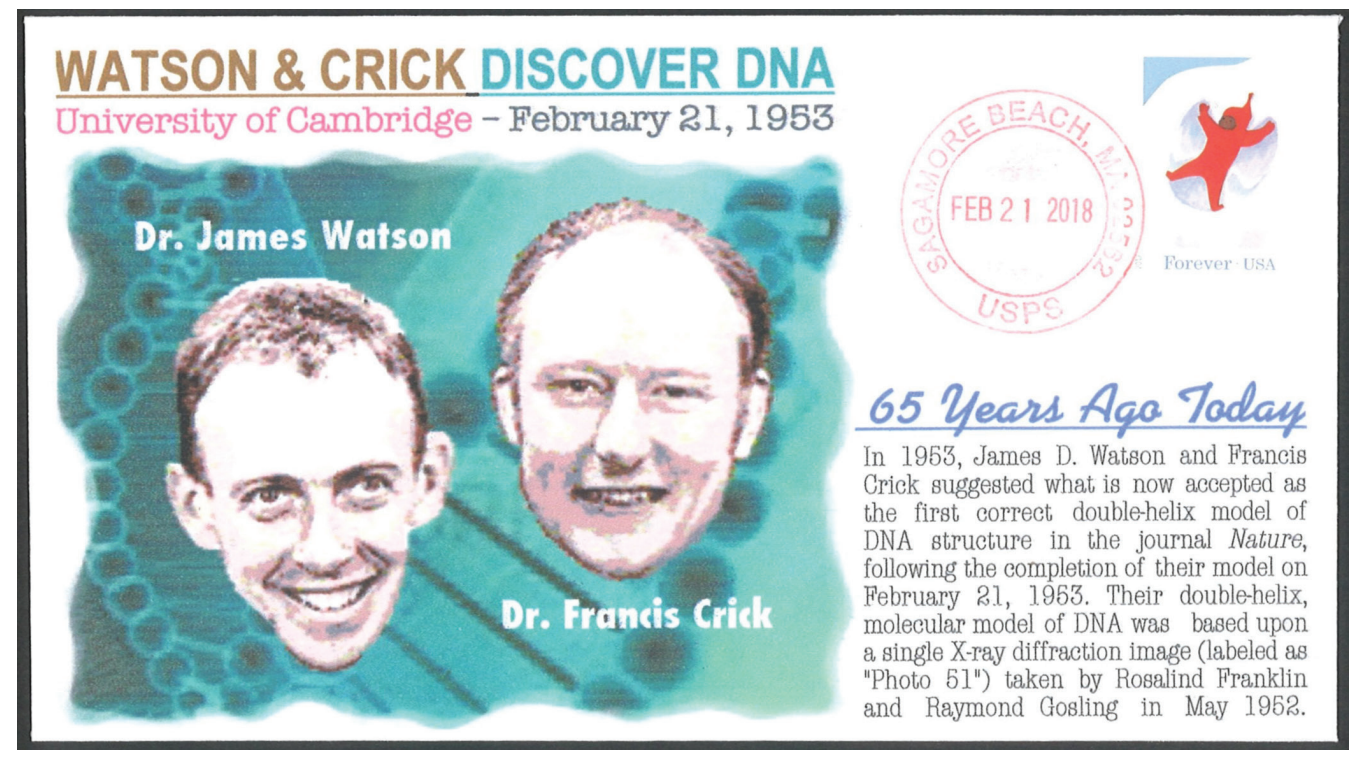

${ }^{1}$ Emeritus Professor of Medicine, University of Hawaii, ${ }^{2}$ Research carried out during transitional residency, University of Hawaii, Honolulu, HI, USA

Correspondence: Prof Tan Siang Yong, 2226 Liliha Street, Suite B-104, Honolulu, HI 96817, USA. siang@hawaii.edu 
AFTER THE DISCOVERY Working at the Medical Research Council's Laboratory of Molecular Biology in Cambridge, Crick next delved into questions such as how the molecule was uncoiled and how the DNA sequence ultimately led to protein structure. In 1957, he proposed the 'central dogma' of biological information flowing one way from nucleic acids to protein. This idea would stand the test of time and help to disprove Jean-Baptiste Lamarck's notion that acquired traits were inherited. He also fathered the 'adaptor hypothesis' in 1958, which predicted the presence of both transcriptional ribonucleic acid (RNA) and ribosomes.

In an experiment of considerable elegance, he and his colleague Sydney Brenner showed that the genetic code was composed of nucleotide triplets, each of which encoded a single amino acid in a protein chain. As they unravelled the mystery of the genetic code, Crick also provided a means for understanding DNA damage and mutation: what happens when a single nucleotide is misread, or skipped over entirely? These errors in DNA replication were called point mutations and frameshift mutations, respectively, and they helped to shed light on how natural selection and evolution might operate, building on the famous work of Charles Darwin and Gregor Mendel.

Crick boldly proposed the idea that life originated from another planet in a hypothesis he called 'directed panspermia'. He would later say that in invoking an external source, he had been too pessimistic about the possibility of life originating on earth. Once the ribozyme, or RNA enzyme, had been discovered, with evidence that RNA could itself act as a catalyst, he was less interested in panspermia because it was then easier to see how life could arise from prebiotic, self-replicating molecules.

CONSCIOUSNESS In 1976, Crick moved to the Salk Institute for Biological Studies in La Jolla, California, in the United States for a one-year sabbatical, which would turn into 30 years of productive research. During this time, he taught himself neuroanatomy and embarked on the study of consciousness. His motivation was simple: "At my time of life I had a right to do things for my own amusement." While at first glance, the subjects of genetics and consciousness seem quite different, they are similar in the sense that both topics resided on science's greatest and riskiest frontiers. When the science of DNA yielded so easily to his prodding, it was natural for Crick to take on the next major question on the minds of scientists and philosophers: what is consciousness? It was a question that few investigators dared to ask, much less try to study, lest they be taken for mystics or New Agers. But in Crick's hands, no question was too awesome or unwieldly.

For his foray into neuroscience, Crick collaborated with Christof Koch, who became a personal friend and who wrote after Crick's death: "Francis Crick was a close personal friend and mentor to me for the past 16 years. He was the living incarnation of what it is to be a scholar: brilliant, rational, dispassionate, and always willing to revise his own opinions and views in light of the actions of a universe that never ceased to astonish him. He was editing a manuscript on his death bed, a scientist until the bitter end."

Together, the two began a search for the neural correlates of consciousness. In 1990, Crick authored the book What Mad Pursuit: a Personal View of Scientific Discovery, which proposed that neuroscience is where molecular biology was at in the 1920s and '30s. His next book, The Astonishing Hypothesis: the Scientific Search for the Soul, identified consciousness as the major unsolved problem in biology and put forward the hypothesis that all subjective experiences, however complicated and religious they might seem, arose from the activity of networks of neurons and their associated molecules. In other words, the mystical 'mind' is nothing more than brain. He urged his neuroscience colleagues to ask their molecular biology friends for help, for he believed that progress in neuroscience depended on a detailed understanding of the molecular basis of brain structure.

Unfortunately, even Crick's great mind was not able to solve the mystery of consciousness. Yet he did succeed in changing people's perceptions of consciousness from quackery to fundamental investigation, and he provided a framework by which scientists could attempt to approach this elusive subject, grounding it in experimental neuroscience. To many, his final paper on the subject was a scientific blueprint and legacy, detailing where he would have taken the investigation if he had had more time.

PERSONAL LIFE Crick was first married to Ruth Doreen Dodd, with whom he had one son. They divorced in 1947. He then married an artist named Odile Speed, whose sketch of DNA graces Watson and Crick's famous manuscript. He and Odile had two daughters. Crick described himself as an agnostic with "a strong inclination towards atheism". He rejected religion in favour of science, wanted natural selection to be taught in public schools and thought there was no place for religious instruction in school. Crick also worked to establish Darwin Day as a British holiday. He supported scepticism in science, donating amply to the cause. In social action, he endorsed a petition to end genital mutilation in children.

It is a sad twist of fate that a discoverer of the double helix ultimately succumbed to a disease of DNA damage. Crick died from colon cancer at 88 years of age on 28 July 2004. He was cremated and his ashes were scattered over the Pacific Ocean. His DNA lives on.

\section{BIBLIOGRAPHY}

- Crick F. What Mad Pursuit: a Personal View of Scientific Discovery. Paperback ed. New York: Basic Books, 1990.

- Crick F. The Astonishing Hypothesis: the Scientific Search for the Soul. Reprint ed. New York: Scribner, 1995.

- Crick F. The Double Helix: a Personal View. Nature 1974; 248:766-9.

- Crick F, Koch C. Consciousness and neuroscience. Cereb Cortex 1998; 8:97107.

- Crick F, Koch C. A framework for consciousness. Nat Neurosci 2003; 6:119-26.

- Watson JD, Crick FH. Molecular structure of nucleic acids: a structure for deoxyribose nucleic acid. Nature 1953; 171:737-8.

- Watson JD, Crick FH. Genetical implications of the structure of deoxyribonucleic acid. Nature 1953; 171:964-7. 